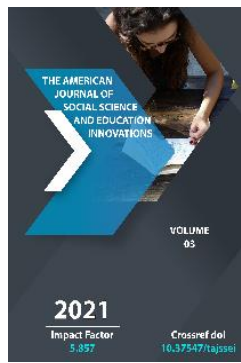

\title{
Theoretical Fundamentals Of Scientific And Innovative Thinking In Adolescents
}

\author{
Komola Atxamdjanovna Farfieva \\ Candidate Of Psychological Sciences, Associate Professor, Head Of The Department Of Philosophy \\ And National Idea, Tashkent State Technical University Named After Islam Karimov, Uzbekistan
}

Journal Website:

http://usajournalshub.c om/index,php/tajssei

Copyright: Original content from this work may be used under the terms of the creative commons attributes 4.0 licence.

\section{ABSTRACT}

The article discusses the theoretical analysis of the role of scientific and creative thinking in adolescents, the means of influencing behavior. The factors influencing the scientific and innovative thinking of adolescents in improving the effectiveness of the system of continuing education, its positive and negative effects have been scientifically analyzed. At the same time, the psychological and social significance of the study of the specificity of scientific thinking in adolescents was emphasized, and the factors influencing their effectiveness were discussed. The author also draws attention to the role of the subjects of the system of continuing education in the formation of a culture of use of various messages in the information space, especially in social networks among young people.

\section{KEYWORDS}

Innovation, information space, adolescence, life position, scientific thinking, intellect, motivation, culture, development, psychological environment

\section{INTRODUCTION}

Introduction. We have come to a point where the only factor that determines success is knowledge, thinking and intelligence. There is no denying how powerful and important 
science is in today and in today's world. Scientists live more meaningful and longer lives, they are more successful. Significant economic, political and social changes are taking place around the world today. Under such conditions, there are great changes in the consciousness and thinking of most people, the differentiation of social perceptions and the expansion of their vital functions. Many people have faced the problem of finding their place in life, choosing their way of life, determining their own way of communicating with society.

Stereotypes for the development of new, forward-looking social, professional, personal self-determination in line with the changes taking place in the world today have not yet been identified. That is why today it is very difficult for young people to distinguish real life and master its norms. This is the source of the ambiguity and uncertainty in the minds of young people today.

Body. Adolescence is a time when you choose your personal and professional path, during which you choose valuable goals and make decisions that are critical to your future life. Reforms in society are accelerating the process of adolescence and youth becoming more mature, more actively involved in the process of solving various life problems. The study of the means by which adolescents influence the formation of scientific-innovative thinking stems from the radical changes that have taken place and continue to take place in society. As the Russian psychologist D.I. Feldstein pointed out, among all the crisis changes, the most important is the change of the person himself. This scientist considers that the self-awareness of growing people, taking into account the above changes, is one of the key issues that requires in-depth study of the issue of their characteristics. Now we are approaching the study of scientific and innovative thinking, as in modern society the demand for creative activity and self-determination of the individual has increased dramatically. Scientificinnovative thinking allows a person to apply existing knowledge in new conditions, to find new connections, to discover new knowledge, to teach the appearance of the environment, to effectively approach new social changes in life. The development of scientific and innovative thinking in adolescents is one of the most significant tasks of today's education system, but the process of scientific and innovative thinking cannot be managed without studying its development on a personal level. The tasks of modern psychological research show that a person's creative potential depends not only on the specifics of the cognitive field, but also on personality traits, and that personal education also affects the structure and productivity of human thinking. As S.L. Rubinstein pointed out, in order to approach thinking in its exact reality, it is necessary to consider thinking in terms of the person. One of the inner rulers of contemplation is the self-awareness of the individual. Numerous works on the problems of creative thinking and self-awareness of the person have been studied by eminent scientists K.A. Abulkhanova-Slavskaya, A.V. Brushlinsky, S.L. Rubinstein, O.K. Tikhomirov, A. Maslow and others. The problem of scientific, creative thinking becomes even more relevant as it is developed in relation to adolescence. This period is crucial for the development of creative thinking and personal self-awareness. During the stealing period, the potential to acquire complex methods of intellectual activity in various fields is demonstrated. This provides a new level of self-development of the individual, the 
formation of "self-image" and a more precise, consistent, stable personalized belonging. At the same time, as I.S.Kon, K.K.Troitskaya, E.A.Shumilin and others have noted, having all the conditions for the formation of creative thinking in adolescence, it either does not develop enough or by becoming unnecessary reduces the level of self-development. It is necessary to study the individual characteristics of the individual in order to provide psychological assistance in the development of creative thinking of high school students and students in the educational process. At present, the problem of creative and scientific thinking has been developed in the research of Yu.A.Mislavsky, N.G.Popryadukhina, S.P.Filippov and others. Feelings, self-esteem, level of inclinations, attitudes as managers of creative thinking activities are considered, but the development of this problem in relation to adolescence remains insufficient.

For modern society, which has entered the path of innovative development, the problem of innovative thinking is becoming the most significant issue related to the identification of psychological and socio-psychological determinants and mechanisms in the formation and implementation of innovative thinking..

It is precisely the psychological problems associated with innovative thinking, innovative activity, innovative behavioral phenomena that have become the focus of serious attention of researchers in many disciplines in recent decades, driven by the demands of modern social practice.

The problem of thinking as a separate subject of psychological research has its own history and multifaceted nature. Many well-known scientists in our country and abroad have been engaged in the study of the laws and mechanisms of thinking of problems of a psychological nature, in their work there is a great empirical material and explanatory mechanisms of some aspects of the thinking process. (K.A. Abulxanova-Slavskaya, A.B. Brushlinskiy)

When it comes to innovative thinking, however, this problem is mainly related to the consideration of the concept of innovative activity, P.Druker, M. Kastels, as well as from Russian scientists, A.Anchishkin, JL Blyaxman, S.Valdaytsev, N. Kondratevs were engaged. The term "innovative thinking", which is widely used in economics, means a new way of thinking in the broadest sense of the word, characterized by the multiplication of new knowledge in the form of innovations and innovations; it is a way of thinking that takes a person beyond the usual scope of existing knowledge, traditional methods of solving problem situations, old views, instructions, habits.

Based on such a broad understanding of the essence of innovative thinking, as well as research to determine its psychological nature, the work on the problems of creative, creative and productive thinking has become important. The phenomenon of creativity is discussed by scientists in different approaches: the quality of the reflective property (A.A. Glazachev, B.M. Runin and others); formation in the interpretation of the dialect of creativity, as a specific type of development (S.N. Semenova, A.T. Shumilin and others); as a peculiar stochastic process in the synergetic interpretation of creativity (B.Il. Nikolko et al.); development, movement as a basis for change (Ya.A. Ponomarev et al.). Creativity category and creative potential appers as a leading 
category in the scientific research of A.L. Gaydjutis, M.S. Kagan, E.V. Kolesnikova, E.I. Meshcheryakova and other researchers. Creativity was researched by M.S. Bernstein, J. Gilford, K.P. Rodgers, S.N. Torrens and others.

Conceptual foundations of innovation psychology (A.G. Asmolov, V.E. Klochko, B.B. Rubtsov, S.R. Yagolkovsky and others) to consider the essence of the concept of innovative thinking, which does not depend on creativity and therefore has its own characteristics and process features of innovative activity, acmeological research (A.A. Derkach, I.V. Kulikova, C.IO. Burda, M.V. Korotaeva, AC Odin g, M.V. Shvydkaya, E.G. Chirkovskaya and others) was carried out, these are related to the study of creative and personal development, emotional culture, psychological and acmeological factors of the introduction of innovative projects, professional self-awareness.

The theory of professional thinking (D.N. Zavalishina, A.B. Karpov, M.M. Kashapov, A.K. Markova, B.M. Teplov and others), as well as the theory of the formation of adult thinking (B.G. Ananev, Yu. .N. Kulyutkin and others), theoretical and practical bases of development of innovative culture of management personnel, and also means of optimization of its development (M.V. Katyshev, L.A. Stepnova and others) are analyzed.

Psychologists V.N. Angonyuk, V.G. Voytsexovskiy, V.F. Galygin, F. Genov, H.A. Ilina, L.A. Korostyleva, M.V. Kroz, O.S. Sovetova and others appealed to the development of a comprehensive provision of innovations, highlighting the phenomenon of psychological barriers to innovation in the field of general innovation, and explained to them the task of forming positive tasks, ie innovation guidelines.

However, the problem of scientific and innovative thinking of adolescents, its sociopsychological appearance has not yet become the object of serious attention in psychological research. As a result, the understanding of innovative thinking remains at the level of imagination, not as a concept, it is not placed in the content of the theory of thinking. The psychological nature and mechanisms of this type of thinking have not been revealed. Its distinctive aspects, the assessment and practical aspects of adolescents's innovative thinking, have been little studied.

The main process in mental activity is the process of thinking, the quality of thinking is determined by its degree of logic, independence, creativity, science, validity, membership, economy, purposefulness, speed, analytics, comparativeness, generalization, privatization, breadth, depth, reliability, reality, validity. However, intellectual qualities are related to the speed and other parameters of memory, imagination, cognition, and similar psychological processes. The higher the level of intellectual development in adolescents, the better the chances of achieving results.

Adolescents develop the ability to perceive a problem, identify it, correctly assume a solution, and verify the correctness of the solution. The solution to the problem can be divided into three stages:

1. Proof, that is, to carry out this problem in the unity of theory and practice.

2. Verification, i.e. substantiation of the reliability of the material with evidence. 
3. Explanation, i.e., the solution to the problem, is done on the basis of identifying the reasons that confirm why it is correct.

Today, the development of young people's worldview on the basis of today's requirements is an important issue for the general public. This can be done through a number of factors. Results can be achieved by overcoming the most important problems in the development of young people's scientific thinking.

Adolescents's ability to think independently should be considered as a criterion for mental development. Therefore, it is necessary to develop the mental abilities of adolescents. It is necessary to develop the ability to radically change the message a person receives from the outside, to solve creative problems, to search for contradictions, to solve problems and find a model, to look for similarities and differences, and in other ways.

Social psychological surveys revealed that there were differences in life perceptions between high school and lyceum students when asked what profession they would like to have in the future to determine their perceptions of the future. While $24 \%$ of high school students surveyed said they were still undecided about which profession to pursue in the future, while lyceum students, on the other hand, said they were more determined about which major to pursue. When asked what motivated your interest in the profession and science, $32 \%$ of the respondents said that their family members, $28 \%$ their teachers, and $40 \%$ were interested in the achievements of various fields of science and technology in social networks. They noted that the imagination of secondary school and lyceum students is expanding, and the need for foreign languages and computer technology will be high in their scientific and social lives, regardless of their future profession. It can be concluded from this that teenagers believe that good knowledge and skills are important for them to become masters of their chosen profession.

\section{CONCLUSIONS}

- In the new socio-economic conditions, the peculiarities of the scientific thinking of adolescents at the stage of development are formed in the field of motivation, the field of thinking and setting tasks, the field of vision of social problems;

- $\quad$ The field of studying the peculiarities of the scientific thinking of adolescents in modern society is formed;

- $\quad$ The relevance and growing number of studies aimed at deepening theoretical knowledge about the essence, nature and manifestation of scientific thinking, as well as deepening theoretical knowledge about the adaptation of man to the modern world, his place in it, his choice of life path.

- $\quad$ The importance of taking into account the specifics of the content and structure of scientific thinking at different ages, the process of educating and training students, the provision of psychological assistance to people, the creation of appropriate forms of behavior in them;

- The study of scientific thinking in adolescence is of particular importance, as it reveals to young men and women new qualitative structures in their thinking, new forms of forecasting and selection, evaluation 
and decision-making mechanisms that control the specific causes of scientific thinking and affect their effectiveness. many vital problems arise that require creation;

- A set of appropriate research methods aimed at studying the peculiarities of thinking in adolescents, the solution of life tasks, predicting the way of life, the peculiarities of thinking in the stages of choosing their place in society;

- It is clear that in the context of the scientific thinking of high school students, perceptions derived from life and experience prevail. The identified differences in key indicators characterizing the structure and content of scientific thinking of students in lyceums, vocational colleges and secondary schools show that the negative impact of social conditions can be overcome by targeting the scientific thinking of adolescents in new teaching conditions.

By studying the psychological peculiarities of the scientific thinking of adolescents, we can make the following practical suggestions:

- $\quad$ More incentives by teachers for those who have achieved positive results in study and community work;

- Explain the analysis of scientific sources in the correct career choices of adolescents;

- Identifying the interests and abilities of adolescents in the profession, creating opportunities for them to study in this area, creating conditions for preparing to enter higher education;
The use of a model of constant motivation for adolescents to achieve specific goals.

\section{REFERENCES}

1. Abulkhanova-Slavskaya K.A. Activity and psychology of personality. - M., Science, 1980.- 333 p.

2. Bodalev A.A. Personality and communication. -M., Pedagogy, 1983. 265 p.

3. Brushlinsky, A.B. The problem of the subject in psychological science // Psychological journal. - 1996.-T.12.-№6.P.3-10.

4. Vygotsky L. S. Thinking and speaking. Selected Works. Vol.2 M.: Pedagogika, 1982.-283p.

5. Karimova V.M., Akromova F. Psychology.Tashkent, 2000. -171 p.

6. Leytes N.S. Mental abilities and age. M., Pedagogy, 1981, - $407 \mathrm{p}$.

7. Matyushkin A.M. Psychological structure, dynamics and development of cognitive activity. // Questions of psychology, 1982.№ 4.- S.5-15.

8. Psychological research of intellectual activity / ed. O.K. Tikhomirova. - I., 1979. $50 p$.

9. Rubinstein S.L. Fundamentals of General Psychology. -SPb.: Publishing House of St. Petersburg. - 2000.- 705 p.

10. Tikhomirov O.K. Psychology of thinking. M.: Academy, 2002. - 287 p.

11. Elkonin D.B. An introduction to developmental psychology. M.: Trivola, 1994.-101 p.

12. Goziev E.G. Psychology of thinking. - T.: Teacher. 1990. - 183 p. 
13. Khikmatov F.Kh. Is Democracy a Strategic Goal or a Means of Achieving It? // International Journal of Innovative Technology and Exploring Engineering (IJITEE) ISSN: 2278-3075, Volume-9, Issue1, November 2019.

14. Farfieva K. A. Social Media as a factor in formation of scientific thinking in youth. European Journal of Research and Reflection in Educational Sciences. Vol. 8 No. 10, 2020. - Pp. 52-56.

15. Atxamdjanovna, F. K. (2020, December). EFFECTIVENESS OF PHYSICAL CULTURE EDUCATION EFFECTS OF ADOLESCENTS ON SCIENTIFIC THINKING IN GROWTH LOCATION OF EFFECTIVE INFORMATION. In Конференции.

16. Фарфиева, К. А. (2019). Роль третьего сектора в формировании и развитии гражданского общества в Узбекистане. European science, (3 (45)).

17. Кулуева, Ф. Г., Фарфиева, К. А., Расулова, М. А., \& Межевникова, О. П. (2020). МАШШАИТЫ: ИСЛАМСКАЯ ИНТЕРПРЕТАЦИЯ ГРЕЧЕСКОГО ФИЛОСОФСКОГО НАСЛЕДИЯ. In European reseach: innovation in science, education and technology (pp. 31-37). 